\title{
The Influence of Management Style and Socio-Cultural Factors on the Education System in the European Union Countries
}

\author{
Monica RADUCAN ${ }^{\star}$, Tincuta VRABIE ${ }^{\star \star}$, Aura COLAN ${ }^{\star \star \star}$, Gianina COLAN ${ }^{\star \star \star \star}$, \\ Nicoleta CRISTACHE ${ }^{\star \star \star \star \star}$, Vasile CRISTIA ${ }^{\star \star \star \star \star \star}$
}

\begin{tabular}{l}
\hline \multicolumn{1}{c}{ A R T I C L E I N F O } \\
\hline Article history: \\
Accepted April 2020 \\
Available online May 2020 \\
\hline JEL Classification \\
I21, I25 \\
Keywords: \\
Socio-cultural indicators, \\
Management styles, Educational \\
system
\end{tabular}

\section{Introduction}

The educational systems in the European Union states are varied and reflect the diverse choices of the society. Despite the differences in terms of organization and financial means, they are based on the common values recognized by the European Education Commission. The option for this research is since there is a pressure on the educational system for performance and finding new ways to increase it.

The purpose of this study is, also, to highlight how the management styles are influenced by certain socio-cultural factors and the impact that the management style has, under the conditions of the sociocultural variables, on the educational system within the European states which are analyzed: Romania, Greece, Sweden, Italy, France, Spain and the United Kingdom.

\section{Literature review}

Management is a discipline centered on people, and the organization`s results are represented by the results of the work managers, of the upper level management, who coordinated the human resource in order to optimize the production (Drucker P., 2011).

Empirical management has begun to develop with the division of labor and human life into organized structures. From the need to make the most accurate and appropriate decisions, a manager must remove the empiricism and base his decisions on science, this way appearing the quantitative school.

The quantitative school cannot fully explain human behavior or predict the way the human resource is operating within the organization; this being the most pronounced limitation of quantitative thinking.

In order to elaborate the decisions, the managers need data, numbers and letters, which they analyze in order to make the best decision. Notable representatives of this school are: A. Kaufman, J. Star, C. Afanisiev, F. Goronzy, etc., all of whom have acquired the features of quantitative thinking (Lazăr I., 2002).

The basic features are represented by the use of mathematical and statistical concepts and methods, using mainly the forecasting and organizing functions of the management; also, R\&D, production and commercial functions are addressed with priority (Burduș E., Popa I. 2018).

The quantitative school appeared through the early 40s, this one using mainly the mathematical and statistical instrumentation in structuring the management concepts, elaborating numerous methods, ideas and concepts through which the efficiency of the carried-out activities can be increased (Burduș E., Popa I. 2018). 
Through the statistical and mathematical methods which are used, the quantitative school provides managers with effective quantitative methods for decision making, while also emphasizing the importance of using computers and software.

The management style illustrates the way managers exercise their authority to ensure that the objectives are met. The style illustrates certain methods of acting and thinking, representing a specific behavior of acting (Popescu G., Vidu A, 2019). It also involves the way managers plan and organize how they work in their area of responsibility, and how they interact with their team members. The key components of management styles are attitudes and behaviours. If managers intend to be efficient, it is important for them to carefully choose how they will perform their duties - what management style best suits both them and the team they have subordinate to and the organization in which they work (Cristache et al). Adopting an improper management style can lead to employee demotivation. In contrast, adopting an improper management style may result in employee motivation (Kaehler B, Grundei J, 2018).

The first theories about management styles focus on how authority is exercised. Based on research conducted at the University of Michigan in the 1950s, Rensis Likert identifies four different styles (Schneider J., Littrell R.F., 2003):

- Exploitative / authoritative: the manager has very little confidence in his subordinates; He exercises his power by giving orders, using fear and punishment as motivational tools

- Benevolent /authoritative: the manager has limited trust in the subordinates and treats them in a paternal way

- Consultative: the manager trusts the subordinates, asks for their opinion regarding the decisions, but retains decision making power

- Participative: the manager trusts his subordinates, makes decisions based on their opinion and involves them in setting goals.

Likert's study suggests that the last two styles (consultative and participative) are the most effective but does not consider the context and atmosphere of the organization in which the manager is, and which is the basis for approaching a certain style.

On the other hand, Douglas McGregor believes that management style is determined by the manager's presumption regarding human nature. In his study, he identifies two large sets of beliefs that he labels as theory X and theory Y (Lamsa T., 2010). Characteristic of Theory X is an authoritarian management style, exercised through coercive type control, receiving formal authority. At the opposite end, managers who adopt Theory Y, will adopt a participatory democratic management style (Lamsa T., 2010).

Theory X: People inherit contempt for work and must be controlled and directed to achieve goals. Thus, for this category we recommend the first two styles mentioned above (authoritarian and paternal).

Theory Y: Work is a natural part of life through which people gain satisfaction. Employees can be motivated to work to their full potential by respecting and recognizing the merits. Thus, it will appeal to the last two styles mentioned above (advisory and participatory).

McGregor believes that while both theories can be effective, management of theory X can lead to low motivation and low levels of performance, while styles adopted by theory $Y$ can lead to high levels of motivation and performance.

According to Reihlen, in the last 40-50 years, management style theories have been dominated first by the American management model, and later by the Japanese model. At the basis of this assumption stands the existence of a management model adapted to each country that derives from the national culture and heritage. Thus, the following two positions have emerged from this theory: culture-free (culture is not an influential factor) and, on the opposite side, culture-contingent (Schneider J., Littrell R. F., 2003).

At the opposite end, the supporters of the "culture-free" position consider that the management style is the result of the business and industrial sectors that generate economic and technological requirements. The way in which managers exercise their power depends on the size, technology and industrial environment that characterizes the organization in which they work, and not the socio-cultural factors of the country or geographical area.

In the current context, where globalization is becoming increasingly prevalent, management styles have become largely uniform at the international level, leaving room for cultural adaptations.

Starting from Farmer and Richman, who argue that effective managerial behavior is influenced by the culture in which that behavior is adopted, the position is now known as a "culture-contingent." The societies present different and persistent cultural aspects that are printed in the thinking and manners models.

According to Professor Andrew Kakabadse and his colleagues, there are four management styles that can be found in Europe: consensus (especially in Finland and Sweden), distance management (France), working towards a common goal (Germany and Austria) and leading form the front (United Kingdom, Ireland and Spain) (Festing M., Barzantny C, 2008).

In Germany, the most common management style is participatory. The managers in Germany expect their employees to possess qualities such as: a high level of qualification and responsibility. The latter do not need a manager to motivate them. They expect their supervisor to assign them certain tasks and solve the 
technical problems they face. Comparisons between similar organizations in Germany, the United Kingdom and France have shown that the Germans have the highest rate of staff in production roles and the lowest rate of leadership jobs (Witzel Morgen, 2005).

British managers focus on communication skills and pragmatism. Politeness, sincerity, control and discipline are cultural characteristics that make them pay more attention to interpersonal skills and persuasion. However, they tend to display an ethnocentric attitude towards foreign employees. Mole believes that British managers are more individualistic. They prefer to focus on tasks and adopt a reserved and respectful behavior, thus creating an impersonal, formal atmosphere (Schneider J., Littrell R.F., 2009). Therefore, it adopts a participatory-authoritative style.

According to Hofstede, French management is characterized by a distant power that concentrates on avoiding uncertainty and on a strong individualism (Festing M., Barzantny C., 2008).

Overall, the employee-manager relationship is characterized by a lack of trust and avoiding direct feedback. Thus, French management is characterized asparticipatory-authoritative.

Italian management is influenced by a cultural characteristic that is prevalent in most national organizations, namely, family businesses. This is not only found in small and medium-sized enterprises, but also in several large organizations. Often, members of the same family are found both in the management and the executive positions. Therefore, we can consider the presence of the participatory style, because the members make the right decision for their organization together (Masino G., 2008).

The hierarchy in the Spanish organizations is of a pyramidal type, with an obvious division between subordinates and managers. The latter provide guidance and make decisions. Subordinates provide information about the operations in the organization and follow the orders. If a problem arises, employees often try to solve it themselves so as not to disturb their manager (Guluță M.C., Rusu C., 2016). The management style used is the authoritative one.

In Sweden, managers use consent in their work. Thus, teams and team spirit are central. They emphasize a common evolution based on effective communication, stability, free discussions in meetings and decision making together. The higher the community spirit, the greater the job satisfaction. Therefore, Sudanese management is a true example of the participatory style (Chamorro-Premuzic T., Sanger M., 2016).

Romanian management is very diverse, but its main characteristic is the adoption of a classic style, ignoring the innovative approaches in the field. The most common style is the paternal one, where the facet of the decisions is hard, reserved only to the manager, on the other hand, the conflict resolution is gentle, often resorting to compromise. The management style used is the authoritative one (Burdus E., Popa I., 2018).

When organizations focus on status and position, managers tend to adopt unique adaptation mechanisms. Such a mechanism is also present in Greece, its name being "kiss up / kick down". This is characterized by: an attention to detail and a pleasant attitude in the relationship with the superiors, while in the relationship with the subordinates they are dominant, giving clear directives and not accepting compromises. Thus, Greece is characterized by an authoritarian management style (Chamorro-Premuzic T., Sanger M, 2016).

\section{Research methodology}

The purpose of the present research is represented by the influence of socio-cultural factors on the management style of the educational system at the level of seven member states of the European Union.

Thus, we can classify the styles identified by Rensis Likert as follows: the exploitative / authoritative style as being par excellence authoritative, the benevolent / authoritative and consultative as being participatory-authoritarian, and the last style presented as being participative.

Following the research of the specialized literature, we identified the predominant management style found in the mentioned countries. These styles are listed in table 1. In order to transform the values from qualitative data into quantitative data, we have assigned values 1,2 and 3 whose significance is recommended, acceptable and respectively not recommended.

Table 1. Countries in theanalyzedsample

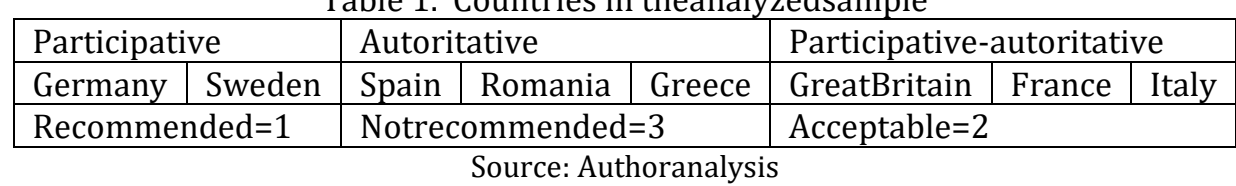

In order to transpose the qualitative data into SPSS we used the notations from table 1.

The dependent variable is the management style, and the other indicators, mentioned in table 2 , are the independent variables.

The objectives of qualitative research through the analysis of certain indicators:

- Analysis of the influence of the management styles mentioned in table 1;

- Determining management styles in the education sector from the 7 countries analyzed; 
- Highlighting the differences regarding the management styles of the states included in the analyzed sample

In order to analyze the socio-cultural factors and influence the management style in 7 member countries of the European Union, the following indicators have been selected:

Table 2. Analyzedindicators

\begin{tabular}{|l|l|l|}
\hline Nr. crt. & Indicators & CategoryIndicator \\
\cline { 1 - 2 }. & Gross Domestic Product & \multirow{2}{*}{ Economic } \\
\hline 2. & CorruptionPerceptionsIndex & \\
\hline 3. & Average and Median Income & \multirow{2}{*}{ Social } \\
\hline 4. & Households Living on the Subsistence Limit & \\
\hline 5. & Participation Rate in Education and Training & \multirow{2}{*}{ Cultural } \\
\hline 6. & People at the Limit of Poverty and Social Exclusion & \\
\cline { 1 - 2 } 7. & Population Living in Severely Damaged Households & \\
\hline
\end{tabular}

Source: Eurostatand Transparency.org

The population is represented by the 28 member countries of the European Union (https://europa.eu/european-union/about-eu/countries ro, 2019) and the sample under analysis is made up of the seven member countries illustrated in table 1.

In order to obtain the data subject to the analysis, the statistical site at European level was used, eurostat.com, the data being from 2016-2018. For the interpretation of variables, both the Office Excel program and the SPSS software were used.

Between education and GDP expenditure, there is a weak and direct, insignificant connection, with the GDP indicator influencing $11 \%$ of education expenditure. The variable "Corruption perceptions index" influences the education expenditure indicator by 10 percentage points, having a direct, weak and insignificant link. Between the variable "Average and median income" and education expenses, there is a strong and direct link, influencing education expenses by $28 \%$. The initiator "Households living on the border of subsistence" influences the dependent variable in a proportion of $25 \%$, with a direct and quite strong link.

The independent variables "Rate of participation in education and training", "Population living in seriously damaged households" and "People on the edge of poverty and social exclusion" do not influence the dependent variable, "Education expenditure".

Further analyzing the correlation between education expenditure, as a dependent variable, and the rest of the indicators, as independent variables, which indirectly affect management styles in the field of education, resulted in the following multifactorial regression equation:

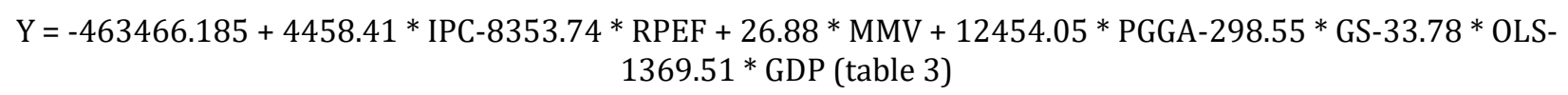

Table 3 is the result of the interpretation of the variables in the SPSS software, resulting in the values mentioned below.

Table 3. Multifactorialregression

\begin{tabular}{|c|c|c|c|}
\hline $\begin{array}{l}\text { Dependent } \\
\text { variable }\end{array}$ & Independent variable & $\begin{array}{l}\text { Regression } \\
\text { equation }\end{array}$ & $\begin{array}{l}\text { Determinacy } \\
\text { ratio }\end{array}$ \\
\hline \multirow{7}{*}{$\begin{array}{l}\text { Education } \\
\text { expenditure }\end{array}$} & Gross Domestic Product- GDP & $\begin{array}{l}y=1531.8 \mathrm{x}- \\
16613\end{array}$ & 0,331 \\
\hline & CorruptionPerceptionsIndex- CPI & $\begin{array}{l}\mathrm{y}=8 \mathrm{E}-05 \mathrm{x}+ \\
52.772\end{array}$ & 0,320 \\
\hline & Participation Rate in Education and Training & $\begin{array}{l}\mathrm{y}=1 \mathrm{E}-05 \mathrm{x}+ \\
9.9899\end{array}$ & 0.0279 \\
\hline & Average and Median Income- AMI & $\begin{array}{l}\mathrm{y}=0.0341 \mathrm{x}+ \\
10279\end{array}$ & 0,521 \\
\hline & $\begin{array}{l}\text { Population Living in Severely Damaged } \\
\text { Households }\end{array}$ & $\begin{array}{l}y=4 \mathrm{E}-06 \mathrm{x}+ \\
13.983\end{array}$ & 0.0135 \\
\hline & Households Living on the Subsistence Limit & $\begin{array}{l}\mathrm{y}=-7 \mathrm{E}-05 \mathrm{x}+ \\
23.257\end{array}$ & 0,481 \\
\hline & $\begin{array}{l}\text { People at the Limit of Poverty and Social } \\
\text { Exclusion }\end{array}$ & $\begin{array}{l}\mathrm{y}=0.0003 \mathrm{x}+ \\
648.73\end{array}$ & 0.0006 \\
\hline
\end{tabular}

Source: Authors`calculations 
There is a medium intensity (quite strong) and direct correlation between management style and education expenditure because the two indicators that measure the intensity of the correlation (Spearman and Kendall) exceed the value of 0.5 . But this interdependence is not very strong because the management style is influenced by other factors.

Table 4 Kendall and Spearman coefficient

\begin{tabular}{|c|c|c|c|c|}
\hline & & & Stil & $\mathrm{Ch}$ \\
\hline Kendall's tau_b & $\begin{array}{l}\text { Costs } \\
\text { education }\end{array}$ & $\begin{array}{l}\text { Correlation Coefficient } \\
\text { Sig. (2-tailed) }\end{array}$ & $\begin{array}{r}-.512^{-*} \\
.002\end{array}$ & 1.000 \\
\hline & $\begin{array}{l}\text { Manag } \\
\text { style }\end{array}$ & $\begin{array}{l}\text { Correlation Coefficient } \\
\text { Sig. (2-tailed) }\end{array}$ & & \\
\hline Spearman's rho & $\begin{array}{l}\text { Costs } \\
\text { education }\end{array}$ & $\begin{array}{l}\text { Correlation Coefficient } \\
\text { Sig. (2-tailed) }\end{array}$ & $\begin{array}{r}-.613^{-*} \\
.001\end{array}$ & 1.000 \\
\hline
\end{tabular}

Source: Data analysisbyauthors

The average value of the management style ( 2 degrees of importance) is a rather unrepresentative value because the variation measured by the coefficient of variation registered a value greater than $35 \%$, respectively of approximately 40\%, this indicator having a low degree of importance because the average value of the expenses for education was 142952.24 units of measurement, unrepresentative value because the value of the coefficient of variation is more than $80 \%$.

Table 5. Average and standard deviation

\begin{tabular}{|l|r|r|}
\hline & \multicolumn{1}{|c|}{ Mean } & \multicolumn{1}{c|}{ Std. Deviation } \\
\hline $\begin{array}{l}\text { Management } \\
\text { style }\end{array}$ & 2.1250 & .79741 \\
$\begin{array}{l}\text { Costs } \\
\text { education }\end{array}$ & 142952.2433 & 116551.58121 \\
\hline
\end{tabular}

Source: Data analysisbyauthors

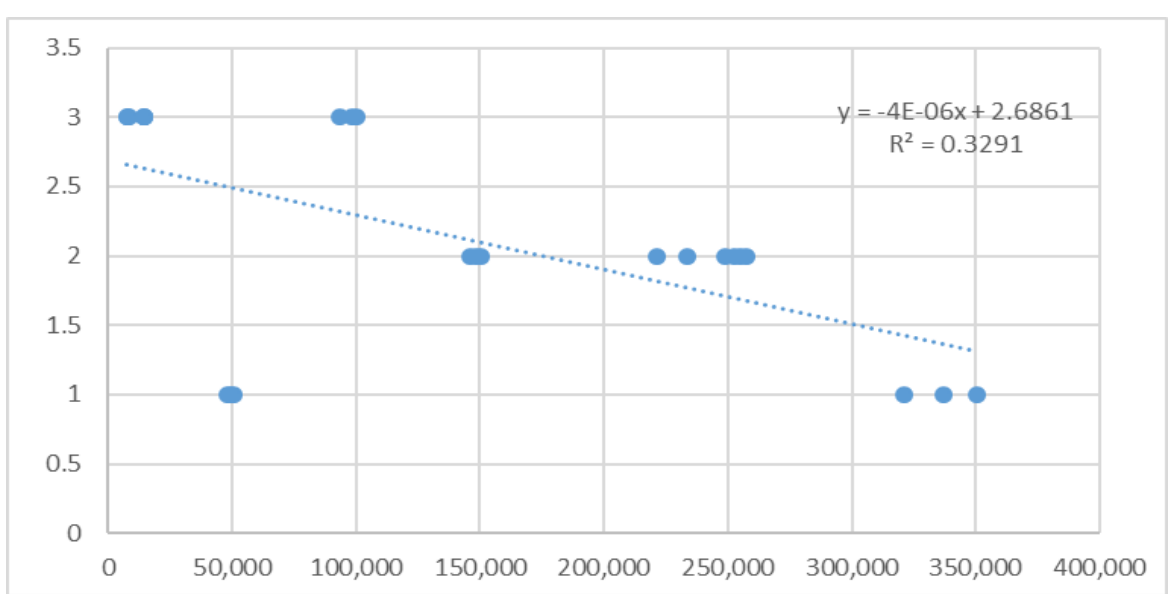

Figure 1. Dependence between management style and education expenditures

Source: Data analysisbyauthors 
Between the management style and the expenditure for education there is a very strong direct interdependence. However, there are other indicators that influence the management style not only the education expenditures, they influence in a proportion of about $33 \%$ the management style (fig. 1)

\section{Conclusions}

The three identified management styles (authoritative, participatory-authoritative and participatory) are present in the educational system of the seven analyzed states, with a higher share of one from country to country. Following the analysis of the specialized literature, the management styles of the countries studied were assigned as follows: 1, being the participatory style, in Germany and Sweden, 2, authoritative, in Spain, Romania and Greece, and 3, participatory-authoritative, in France, Great Britain and Italy.

The variables that influence the expenditure indicator for education are: "Gross Domestic Product", "Corruption Perceptions Index", "Average and Median Income" and "Households Living on the Subsistence Limit", the other independent variables not influencing the dependent variable.

The indicator "Average and median income" most influences the variable "Education expenditure" in a proportion of $28 \%$.

The management style, as a dependent variable, is influenced by the independent variable of expenditure on education, in a proportion of $11 \%$, with a weak and direct connection.

In conclusion, we can say that the education system in the analyzed countries is partially influenced by some of the indicators studied. We recommend that an increase in education expenditures be made to streamline the educational system so that higher level management in this field can fulfill its duty towards society; education should become a priority for all states, not just for the developed ones.

\section{References}

1. Burduș E, Ion Popa, Fundamentele Managementului Organizației, Editura Pro Universitaria, 2018;

2. Chammoro-Premuzic Tomas, Sanger Michael, What leadership lookslike in differentcultures, articol publicat în Harvard Business Review, 2016;

3. Comisia Europeană, Sistemele de educație, 2016, https://ec.europa.eu/info/sites/info/files/file_import/european-semester_thematicfactsheet_education-systems_ro.pdf;

4. Cristache N., Nastase M, Petrariu R., Margareta Florescu M., Analysis of congruency effects of corporate responsibility code implementation on corporate sustainability in bio-economy, Revista Amfiteatru Economic, ISSN: 1582 - 9146, vol. 21, Issue: 52, aug 2019;

5. Drucker Peter, Management, Tasks, Responsibilities, Practices, Editura Routlege, 2011;

6. Festing Marion, BarzantnyCordula, A comparative approach to performance management in France and Germany: The impact of the European and the country-specific environment, European Journal of International Management, 2008;

1. Guluță Marius Constantin, Rusu Costache, Leadership stylesand managerial behavior in Romanian companies, Polish Journal of Management Studies, 2016;

2. Kaehler Boris, Grundei Jens, HR Governance A theoreticalintroduction, Editura Springer, 2018

3. LamsaTuija, Leadership Styles and Decision-making in Finnish and Swedish Organizations, Review of International Comparative Management, Vol. 11, ediția 1, 2010;

4. Lazăr Ioan., Evoluția Științei Managementului, Revista Transilvană de Științe Administrative, VIII, 2002;

5. Masino Giovanni, Culture and Management in Italy: tradition, modernization, new challenges, Presse de l'Université Laval et Téléuniversité, 2008;

6. Popescu George, Vidu Adela, Identificarea Stilurilor de Management, https://www.academia.edu/16451412/Stiluri_de_management, acces 19.11.2019;

7. Schneider Judith, Littrell Romie Frederick," Leadership preferences of German and English managers", articolpublicatîn Journal of Management Development, 2003;

8. WitzelMorgen, The encyclopedia of thehistory of American management, Editura Continuum, 2005. 